\title{
Design and assessment of an adherence monitoring device for inhalers
}

\author{
Richard Costello ${ }^{1 *}$, Richard Reilly ${ }^{2}$ \\ From EAACI International Severe Asthma Forum (ISAF 2012) \\ Gothenburg, Sweden. 11-13 October 2012
}

\section{Background}

Inhalers are widely used in the treatment of asthma. Non-adherence to inhalers is considered to be a contributing factor to poor control of this condition. Nonadherence with inhaled medications may arise because the drug is taken at incorrect times or when the correct steps in the use of the inhaler are not followed.

\section{Methods}

We designed a device with a high fidelity microphone and small sized acoustic storage to make time stamped acoustic recordings of an individual's use of an inhaler. We related the acoustic features to the various steps involved in the correct use of an inhaler. We established a minimum acoustic profile required to use the inhaler correctly, thereby objectively quantifying technique. A cohort of subjects with moderate/severe asthma $(n=44)$ used a salmeterol/fluticasone discus inhaler with the device attached for a month. The subjects were instructed in the use of the inhaler.

\section{Results}

There was almost a full correlation between the number of audio files in which drug priming occurred $(\mathrm{n}=1674)$ compared to the number of doses administered $(n=1687)$. Analysis of the recordings indicated that $6(18 \%)$ had missed more than $20 \%$ of doses and 7 (21\%) had more than $20 \%$ of doses with an error. The most common error was that subjects blew into the device, after the drug was deployed and with sufficient force that the drug was dispersed $(n=184)$. Overall, $19(57 \%)$ had more than $20 \%$ doses with an error in timing or technique.

${ }^{1} \mathrm{RCSI}$, Medicine, Ireland

Full list of author information is available at the end of the article

\section{Conclusion}

These studies indicate that this device and associated processing may be useful for the management of conditions such as severe asthma.

\section{Author details}

${ }^{1}$ RCSI, Medicine, Ireland. ${ }^{2}$ Trinity College, Dublin, Engineering, Ireland.

Published: 3 May 2013

\section{doi:10.1186/2045-7022-3-S1-P9}

Cite this article as: Costello and Reilly: Design and assessment of an adherence monitoring device for inhalers. Clinical and Translational Allergy 2013 3(Suppl 1):P9.

\section{Submit your next manuscript to BioMed Central and take full advantage of: \\ - Convenient online submission \\ - Thorough peer review \\ - No space constraints or color figure charges \\ - Immediate publication on acceptance \\ - Inclusion in PubMed, CAS, Scopus and Google Scholar \\ - Research which is freely available for redistribution

